$\mathbb{T}$ periodica polytechnica

\author{
Social and Management Sciences \\ 20/2 (2012) 105 \\ doi: 10.3311/pp.so.2012-2.05 \\ web: http://www.pp.bme.hu/so \\ (c) Periodica Polytechnica 2012
}

RESEARCH ARTICLE

\section{Applying technology roadmapping for the energy saving industry}

Szilvia Bíró-Szigeti / Béla Pataki

Received 2012-06-20

\begin{abstract}
This paper discusses some issues of residential energy saving technologies in Hungary, applying a relatively new method. Coordination of public and industry investments - compling with sustainability criteria - has come up against several difficulties up to now. These problems originate mostly in the long-standing lack of the comprehensive strategic plans containing concrete objectives and state's guidelines for the household market of building energetics products and services. The authors' purpose is to analyse this market from a strategic point of view, and to process the available information using technology roadmapping, as well as to draw conclusions about the practical fruition.
\end{abstract}

\section{Keywords}

building energetics project · energy saving - energy policy . residential energy saving investment $\cdot$ technology roadmapping · TRM

\section{Szilvia Bíró-Szigeti}

Department of Management and Corporate Economics, BME, Budapest, 1117, Magyar tudósok körútja , building Q, A-309, Hungary

e-mail: szigetisz@mvt.bme.hu

\section{Béla Pataki}

Department of Management and Corporate Economics, BME, Budapest, 1117, Magyar tudósok körútja , building Q, A-309, Hungary

e-mail: pataki@mvt.bme.hu

\section{Introduction}

Energy industry became one of the leading industries regarding its strategic importance and presence in our everyday life and its sustainable development. Macroenvironmental effects influencing energy generation and consumption made energy saving an important issue in households as well. But the stakeholders of the investments often make the implementation of energy saving efforts more difficult themselves because of their misbeliefs and lack of information or sometimes previous negative experience, while energy prices, claims for conveniences, and the effects of residential energy savings on national economy are all increasing.

We call 'energy saving investments' or 'building energetics projects' the realizations of different activities aiming energy saving with new facilities or additional features of existing facilities in buildings in the domestic or organizational segments of the market. We use 'building energetics' expression that includes all building industry products and services (electrical, mechanical, etc.) that actively or passively influence the energy consumption of the building. The 'residential building energetics investments' means building energetics products and services that are purchased by the households for long-term use.

In the course of the feasibility studies of Hungarian residential energy saving investments - when analysing the conditions and the market of energy saving solutions - a knowledge gap occurs between the necessary and available basic information. Studying the traditionally examined factors is vitally important but not enough in itself. There is a lack of indispensable information which should be examined and used but is disregarded by Hungarian research and literature. The state and market level energy policy are not worked out with processing all the necessary information in a systemic way, using management methods of high standard like technology roadmapping (TRM). In this paper we would like to contribute to the filling of this methodological gap.

The gathered information was summarized in the form of a rough technology roadmap, showing natural, economic, and social changes and demands, the direction of the necessary energy political steps, and development tendencies of some technolo- 
gies. The complete technology roadmap can be useful eminently for the state level energy policy makers and for the players of the market of building energetics products and services.

In the present paper we do not describe the technology roadmapping method in general because it was already thoroughly discussed in several papers, see e.g.: [2, 22, 28, 29, 37, 41, 47]. Now we apply technology roadmapping on industry-level, to the Hungarian domestic energy saving investments, based on the available information.

Hronszky and Várkonyi [18] distinguish two main kinds of industry-level roadmapping. One is forecasting when future trends are more or less predictable, and the other is foresighting when future events are very uncertain. The energy saving technology roadmap showed in this paper is an example of the second type, supporting technology foresight. This method can adopt even radical changes of the trends, and can be adapted to them henceforth.

Technology roadmapping is a widely used method all over the world for developing economic and social policies, making environmental decisions, introducing legislations, and laying down $\mathrm{R} \& \mathrm{D}$ guidelines that contribute to the national level energy policy. 159 publications are listed in the literature [46], which support the application of technology roadmapping in the field of energetics.

\section{Technology roadmap of residential energy saving in- vestments}

In this section we present the background information and specification needed to draw the technology roadmap of residential energy saving investments and interpret the data shown on roadmap (see Fig. 1).

This kind of roadmap can provide useful information in two ways. On the one hand it can be used by the state to form the residential-level energy policy. On the other hand companies can use it when they are working on their technology strategies and development plans. The industry-level strategic roadmap of the household market of building energetics products and services was assembled using international (Japan, USA) examples and recommendations. Worthy of note that this roadmap needs much detailed elaboration, this paper can be only the starting point and methodological guidance for a thorough research.

It was important to begin the roadmap with looking back for cca. a decade because the roadmap shows a process which started earlier. Our chosen starting point is year 2000 because it is frequently used as a starting point in the literature. The most important events which contributed to residential-level energy saving since 2000 are plotted on the roadmap.

\subsection{The structure of the roadmap}

The roadmap is made up of layers which represent the usual structure of macroenvironmental analysis: social, technological, economic, (energy) political, and in this context natural (ecological) factors. These are the well known macroenvironmental fac- tors of the STEP model [1] which was extended in several ways (e.g. STEPL with 'legal' or STEEP with 'ecological' added). The 'political' layer means energy policy in this context. Worthy of note that energy policy can be connected to every other layers because residential-level building energetics is a tightly state controlled industry. The particular entities on the roadmap could be assigned for more than one environmental factor, so this layout is only one of the possible graphing structures. In the present structure the roadmap can be interpreted from up to bottom most easily. Continuous arrows represent forward effects, i.e. the macroenvironmental factors influence the energy policy and they together influence the technological development. Technological development tendencies retroact to the macroenvironmental factors and a cyclic process takes shape this way. Because of existing knowledge gaps our rough pilot roadmap does not show these directly related existing or emerging factors that are mutually prerequisites of each other, or the specific interactions and other linkages. We only indicated the typical linkages among the layers instead of the particular entities within the layers, and the directions of the spill-over effects. This kind of diagramming is different from the usual TRM graphing method when the linkages between the particular entities must be drawn onto the roadmap to make complete. This kind of graphing is unusual but - we think - expressive.

The roadmap shows what kind of trends can be expected during this century on the grounds of the most typical forecasted data. It also shows the expected effects of these trends to the energy saving and energy efficiency improving technology development which can happen on macroenvironmental level.

The three environmental dimensions at the bottom of the roadmap are natural (ecological), economical and social factors. These three factors are the keystones of sustainable development as well. Ideally states form their energy policies considering all of these three factors which influence the technology areas to be developed as shown on the roadmap. During the past centuries natural environmental factors were neglected and the effects of social factors were taken into consideration only from the energy demand point of view. This antecedent caused the present imbalance and that is why a radically renewed energy strategy.

Due to the limitations of the applied roadmap drawing software, the map is not true-to-scale. Data of the 2000-2010 period are given to advance the understanding of antecedents and future tendencies.

\subsection{Legend}

- Date (years): we marked most of all characteristic dates and periods. The roadmap is not true-to-scale. We drew altogether three periods.

- Categories: by macroenvironmental factors (technological, energypolitical, social, economical and natural).

- Subcategories: we divided the macroenviromental factors into subcategories. We classified the sustainability factors 
into macroenviromental subcategories.

- Arrows:

- continous line: marking of progressive effects and progresses:

○ broken line: marking of reaktive effects and progresses:

- Flag with data: marking the information and data in a point of time:

- Formal appearances of formations:

- Phenomena:

- Rising tendency:

- Declining tendency:

- Firm tendency:

Rising then declining tendency:

$\circ$ Events:

\subsection{Identifying the knowledge gaps}

It is important that during every step of the technology roadmapping process the knowledge gaps have to be clarified [42]. The necessary information for assembling the technology roadmap of the Hungarian residential-level energetics is partly missing in the literature. We summarize this fragmented information using the insights and recommendations of [11], [5], [26], [49], [45], and [52] about producing a proper roadmap. Industry-level energy generation is widely covered in the literature but there are only a few cross-references to the residentiallevel, so the adaptation of the roadmap to the circumstances in Hungary must be limited. That is among others why the expected technological information and other numbers on the roadmap are taken from a document published by the Japanese Ministry of Economy, Trade \& Industry [19], corrected slightly when it was customized to the situation in Hungary.

We identified the following knowledge gaps:

- new energy policy strategic programs, directives, elements of fiscal policy;

- need for radical innovations or such new technological trajectories that are not yet visible or are still in the critical experimental phase;

- the missing separation of the changes of the factors that can be examined with an extrapolative or normative approach along the time axis;

- breakpoints and nodes that determine the occurrence of future events;

- new cultural effects that considerably influence the energy consumption and the range of energy sources in the future. The roadmap contains the estimations based on the previously known consumption habits and behaviours.
- regional characteristics that influence the range of applicable technologies and the energy strategy guidelines;

- concrete priorities (the roadmap contains the different technological and energy policy areas in general);

- representing concrete linkages and relationships on the map;

- future trends and counter-trends, and potential but unexpected events (mainly in case of the environmental, economic and social factors) that can influence the foresight and cause a shift in any field;

- changes in attitudes, motivation and resources required from the stakeholders with time, and their collective and investment risks;

- systematic analysis of the customer types, environmentconscious thinking, and energy saving attitude in Hungary.

The majority of the knowledge gaps listed above originate in the lack of the detailed energy strategy in Hungary. There has not been considerable top level ownership of this issue on the part of the state until recently. However it can be considered some progression that the ownership appeared as one of the state's unambigous roles in the new national energy startegy recently [33]. Really serious technology roadmapping can be accomplished only with the joint efforts of several participants. Only politicians whose scope of authority entirely covers the necessary fields can involve all the required experts into this teamwork. Creating a fully comprehensive residential-level energy saving technology roadmap would fill such a gap in the Hungarian energy policy which is indispensable for the state's consistent energy strategic decision making in the future, which is quite an imperative issue.

Due to some limitations and knowledge gaps, the lack of concrete data for residential building energetic sector in Hungarian energy strategy, a comprehensive roadmap can not be developed within the frame of this work. The knowledge gaps could be bridged by an extended and deeper analysis and presentation of further important factors. Our aims were as follows:

- to demonstrate the usability of technology roadmapping for establishing residential-level energy saving technology policies and strategies,

- to delineate a pilot version of the technology roadmap, as a starting point of the fully comprehensive development, and

- to show the potential benefits of its application in technology political and strategic decision analysis.

Another limitation is that the development of a comprehensive roadmap can only be carried out in a multi-disciplinary team of experts with the "ownership" of a high-level politician, responsible for the given field. This is far beyond the knowledge of an individual expert. 


\subsection{Customizing the industry-level technology roadmap}

In the course of the customization of the industry-level roadmap we chose only those macroeconomic factors to be plotted which have the most significant impact on residential energy saving in the future. Four points of time are signed on the roadmap: 2000, 2010, 2030, and 2050. This 50 years long time interval is long enough to be considered on a strategic level and also long enough for the main trends of technology developments to emerge. We chose a 50 years time horizon in spite of the fact that the Japan energy strategy [19] which is the most detailed one found in the literature, applies a 100 years period. In our opinion any longer time interval than the one we chose would be too long for making forecasts and for trying comprehensively outlineing because innovations can rarely be foreseen, they often come unexpectedly, disrupting the previous forecasts. The IAE also proposes using a maximum 50 years period in its energy technology roadmaps guide [20].

The underlying assumption behind most of the information on the roadmap is linear extrapolation. But some authors [9, 18, 25] emphasize that this way of thinking is inadequte for projecting a picture of the future. According to these authors the imaginations of the future of technological development are unsound in most cases because usually the present courses of proceedings are linearly extrapolated intuitively, but in fact they can be characterized with exponential curves as a general rule. This way an intendment barrier arises and even the otherwise perceiveable becomes unperceiveable. Physical factors which typically characterize the residential sector [8, 19] are listed below. These factors must be considered in residential-level if the currently most frequently used technologies are planned to be substituted with energy saving technologies or completely taken over by alternative technological solutions in the future:

- energy demand and $\mathrm{CO}_{2}$ emission are small in general on individual level, but it is sinificant in numerous consumption places,

- consumption places are differentiated,

- emission is not concentrated,

- there is strong dependence upon temperature,

- it is a major pollute-source in winter,

- properties that require reconstruction or renewal are cca. 20100 years old.

On the technology roadmap of the Hungarian building energetics industry those main technological specifications are summarized which mostly need innovation for the energy saving operations of the households. The technological development requirements of the particular periods are based on the Japan energy strategy [19]. Apart from Japan the USA has a detailed residential-level strategic energetics technology roadmap [4, 38, 40]. In the European Union general directives can be found for the time beeing - in the first place for energy generation, but a concrete residential-level energetics technology strategy is not known yet [7].

The main technological possibilities appearing in residential energy saving areas are as followes [19,31]:

- Development of new lighting technologies: conservation and using natural light, different models of LED, with low heat loss and high efficiency luminous bodies.

- Development of HVAC (heating, ventillating, air conditioning) and hot water supply: to replace air-conditioning equiment, to equip heat pump and solar collector, to use unused energy/heat.

- Energy saving planing and construction materials for housing and building: developing materials for thermal insulation and applying to building materials. Spreading high quaility housing by convenient and highly accurate housing performance desgin and assessment technologies.

To fulfil the required technological specifications in the residential sector the energy consumption must be reduced as measurably as possible in the first place. At this point those household appliences and pieces of equipment should be taken into consideration that will come out only in the future. In the second place such energy generation methods must be found that utilize continuously available renewable resources like solar and geothermal energy. Those technological solutions and decentralised systems are prioritized which are self-supplying, independent from the fossile energy sources or the energy networks. In this way only less energy produced by the existing (centralised) energy system must be transmitted for long distances, consequently efficiency can increase and energy generation demand can decrease.

The most important technological requirement in the residental building energetics sector is that the energy consumption per household must be reduced by $80 \%$ till 2100 , in spite of the fact that in the same time the energy consumption's share within the GDP is expected to continually increase [7]. Increasing proportion of energy consumption within the GDP appears to be unavoidable because every government tries to raise the living standard but it involves more demand for energy [7, 14].

The share of electric energy within all types of energy should reach $100 \%$ by 2100 . Within electric energy the proportion of fossile energy sources should be continually decreased. This requirement involves that the energy demand of buildings and household appliances, the usage of long distance transmission line networks, the magnitude of centralized energy generation, and $\mathrm{CO} 2$ emission must be reduced. The proportion of renewable energy sources and operations by using electricity must be increased while the users' comfort level and other requirements must be maintained [10, 14].

We show energyresouce constraints too on the roadmap: up to the expected production peaks (oil: 2050, natural gas: 2100). 


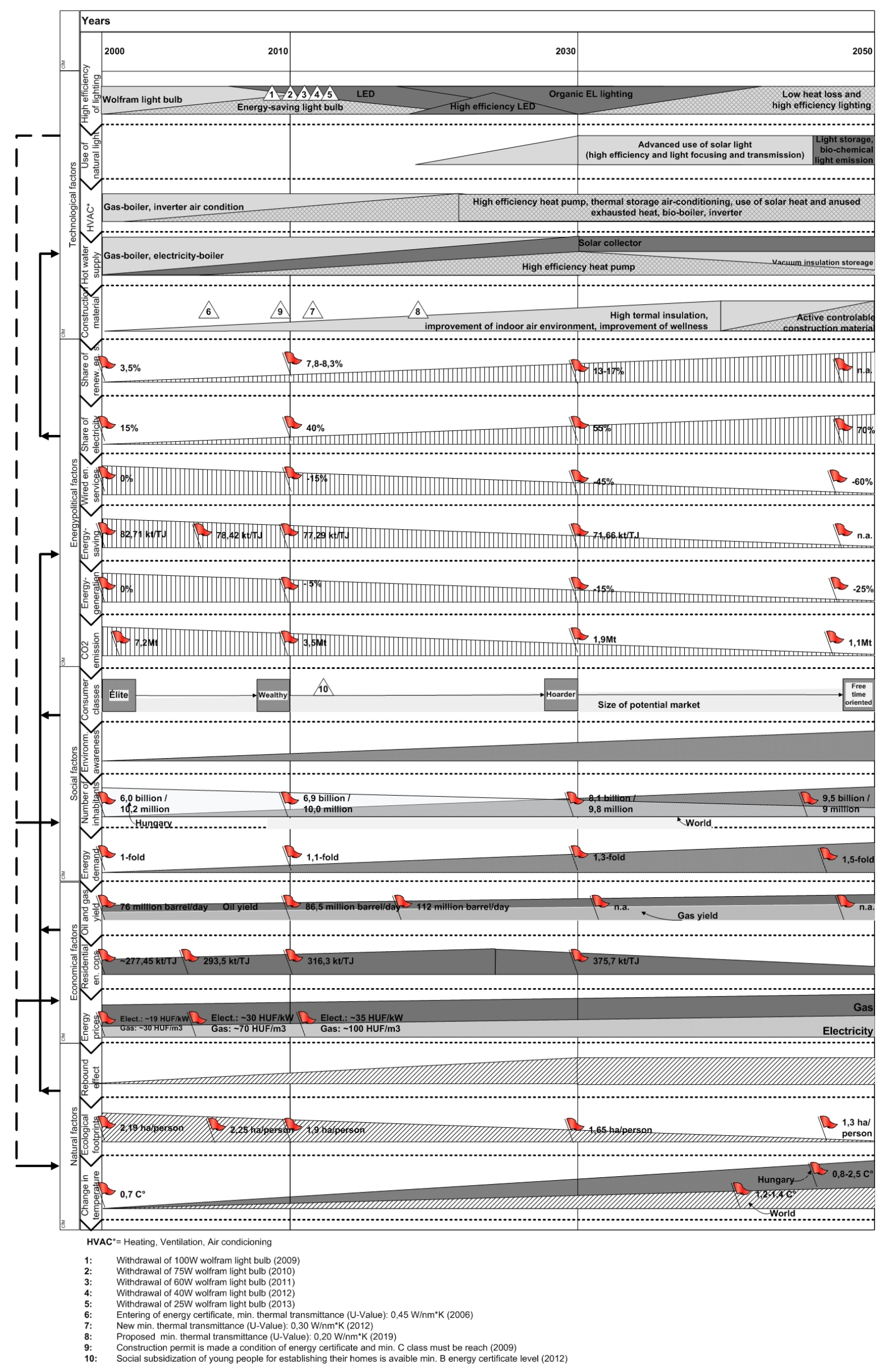

Fig. 1. Technology roadmap on the Hungarian residential energy saving. 31, 32, 34, 35, 37, 38, 39, 43, 45, 47, 49, 50, 52, 53] Using data from $[3,4,6,7,8,10,12,13,14,15,16,17,19,23,24,27,30$, 
Thereafter we have to be reckon with progressively decreasing supply and ever higher prices [14].

Energy demand could be reduced if population decreased [46], energy conscious way of thinking and lifestyle spread, and the demand for air conditioning decreased as a result of complex energy saving housing (houses with low energy demand, passive houses) [19,31].

Using energy saving technologies not only reduces energy consumption but improves the quality of life and changes the lifestyle. The goal is that self-dependent energy creation and the usage of renewable energy sources at local communities should become typical [19].

By favour of the spreading environment-conscious thinking and technology applications broader and broader consumer range (light backgrounded layer of the consumer classes sublayer) and consumer categories with lower an lower income levels (squares of the consumer classes sublayer) can be reached and involved into saving energy. This process is demonstrated by graphing consumer groups of the particular buyer types defined by Fábián et al. [15] along the time axis. These authors separated the main groups of Hungarian society in the course of their research in virtue of three ranking criteria: flat, material and cultural consumption. The first group is the elite characterized by outstanding material and cultural consumption, the second is the wealthy group, the third is the hoarder group, the fourth is the free time oriented group, and the fifth is the deprivated group with good flat. Members of the last group can fulfil their basic needs above the average but their material and cultural consumption is below the average. At the bottom of the consumption hierarchy we can find the most disadvantageous group of deprivated poor people in virtue of all ranking criteria. Building energetics investments can be accomplished in the first place by the members of the first three groups (elite, wealthy, hoarder) because of their motivation, values and financial situation. The conclusion of their research is that the exploration of the possibilities of crossing the boarders of the separate consumption models could contribute to the motivation of some particular consumption patterns and to the understanding of the tools of influencing the formation of consumption patterns. The above mentioned societal process is reinforced by the energy certification system, namely the social subsidization of young people for establishing their homes is available only with " $\mathrm{A}+$ ", "A" or "B" property energy classes from 2012 [32].

In the course of the reduction of the energy demands the so called rebound effect must be considered and handled. Rebound effect or Jevons paradox (sometimes Jevons effect) [21] is the proposition that technological progress that increases the efficiency with which a resource is used, tends to increase (rather than decrease) the rate of consumption of that resource. The issue has more recently been reexamined by modern economists studying consumption rebound effects from improved energy efficiency. In addition to reducing the amount needed for a given use, improved efficiency lowers the relative cost of using a re- source, which increases the quantity demanded of the resource, potentially counteracting any savings from increased efficiency. Additionally, increased efficiency accelerates economic growth, further increasing the demand for resources. Handling the rebound effect can be achieved by developing an energy-conscious behaviour, because the largest energy saving is the not consumed energy. The magnitude of rebound effect increases at first but a constant level can be achieved by enhancing the environmentconscious behaviour [17].

Climate change and population growth determine the size of the ecological footprint. The running out of our energy resources, the decreasing natural ground area, and the increasing population are continuously reducing the size of the ecological footprint per capita while the inhabitants of the developed and developing countries have bigger and bigger ecological footprints [36]. The less is the magnitude of the rebound effect and the more efficient is the operation of the new energy saving devices, the higher living standard can be achieved with the same ecological footprint size [17].

At last but not least one of the most serious natural factors urging energy saving is the rise of the average temperature, resulting in climate change. Signs of climate change appear in temperature and precipitation intensity and frequency contexts in Hungary [35]. Expert opinions diverge about of the magnitude of this future change, but this problem must be taken seriously and must be dealt with.

\section{Some anticipated future trends of TRM}

\subsection{New TRM-application types}

We anticipate that the company-level and industry-level applications of TRM will converge and new company-level users of the roadmaps will emerge in the same time. Trade alliances (possibly with government support) could make general roadmaps of their industries. Companies of those industries could use those industry-level technology roadmaps when they create their own corporate-level roadmaps and would save a lot of time and effort this way.

Not only the companies of the particular industry can use fruitfully the industry-level roadmaps. The energetics industry is a very good example of this anticipated trend. Every company, regardless of its industry, could have an energystrategy roadmap that contains planning and timing of its energetics technological investments: when, what and how to develop their buildings, plants and other facilities to improve their energy-efficiency. Like the companies of the industry itself they also would follow the updates of the industry-level roadmaps and update their own company-level technological investment roadmaps in accordance.

\subsection{Standardization}

Standardization would be advantageous for the general usage of TRM anticipated above. Technology roadmapping has no graphing standards like e.g. project management. The standard 
versions of e.g. network diagrams can be learned from several project management books and other teaching media. These graphic project management tools are more or less standardized, like the symbols of electronic circuit diagrams. In TRM there are only several examples but not standardized diagramming techniques. We expect some kind of settling down of this disarrangement and the beginning of a standardization tendency in roadmap diagramming in the near future. It would be beneficial for making roadmaps easier to plot and to read as well. We are sure that nobody can create any single universal roadmap type because different application areas and goals need different types of roadmap symbols and graphing rules. But it is not indifferent how many and how different types. Less would be more.

In line with the general standardization we anticipate another future trend: standardizations within the individual application areas. A good example is the energy strategy roadmap. In this area it would be possible and beneficial to standardize symbols, graphic tools and terminology what energetics experts use. The general level standards should be known and used by everyone who draws or reads technology roadmaps, while the application area level standards by those who work on the particular field of expertise.

\section{Conclusions}

Based on the available literature sources we assumed that technology roadmapping can be used to describe the complex conditions of the Hungarian residential building energetics investments, and support their realisation. In the course of the information gathering and processing and the development of a methodological model, we assumed that nowadays the technological and macro level information is (at least partly) available. A model developed based on this information can pursue a longterm and coherent energy policy and strategy.

We stated the following findings in the course of information exploration and model building. It was foreseeable from methodological point of view that the development of a comprehensive roadmap can not be carried out at present because of the very limited number of researchers. Just a multidisciplinary team of experts could continue this work, because it is far beyond the knowledge of one or two experts.

The technology roadmap is not complete in its present form. In order to improve it we collected the most important elements of the knowledge gap. It is worth highlighting that the main problem lies in the lack of a residential energy saving strategy. Currently Hungary does not have a comprehensive, detailed, and coherent energy strategy with concrete objectives (supported by figures and feasibility studies). The available guidelines and concepts are not adequate. The regulating and coordinating role of the state, as well as the market liberalisation are essential for the next steps. The state has to be the top-level owner of the industrial roadmap, otherwise no serious results can be achieved.

\section{References}

1 Aguilar F J, Scanning the business environment, Macmillan, New York, 1967.

2 Albright R E, Kappel T A, Roadmapping the Corporation, IEEE Engineering Management Review 31 (2003), no. 3, 32-41, DOI 10.1109/EMR.2003.24903.

3 Andor L, Olaj és politika. Két változat az intervencióra, (Oil and politics. Two versions of intervention)., Politikatudományi Szemle 13 (2004), no. 3, 71-96, available at www.poltudszemle.hu/szamok/2004_3szam/2004_ 3_andor.pdf Retrieved: 23. 03. 2012.

4 BPA - Bonneville Power Administration, Energy Efficiency Technology Road Map, BPA Technology Innovation Office, USA, 2006, available at http://wWw.bpa.gov/corporate/business/innovation/ docs/2006/rm-06_energyefficiency-final.pdf Retrieved: 23. 03. 2012.

5 Brummel A, MacGillivray G, Introduction to scenarios, http://scenarios2strategy.com/pdf/Introduction/ $\{\%\} 20$ to $\{\%\} 20$ Scenarios $\{\%\} 20$ and $\{\%\} 20$ Scenario $\{\%\} 20 \mathrm{Planning}$. pdf Retrieved: 23. 03. 2012.

6 Commission of the European Communities, Communication Staff Working Document - Accompanying document to the Proposal for a Recast of the Energy Performance of Building Directive, Impact Assessment, 2008, available at http://ec.europa.eu/energy/strategies/2008/doc/ 2008_11_ser2/buildings_impact_assesment.pdf Retrieved: 23. 03. 2012.

7 Commission of the European Communities, A Technology Roadmap for the Communitaion on Investing in the Development of Low Carbon Technoilogies (SET-Plan), 2009, available at http://setis.ec.europa. eu/about-setis/technology-roadmap/Complete\{\%\}20report.pdf Commission staff working document. SEC(2009) 1295: Brussels.Retrieved: 23. 03. 2012.

8 Csete J, Horánszky B, Szunyog I, A lakossági energiafelhasználás környezetterhelése (Enviromental load of residential energy consumption), Energiagazdálkodás 46 (2005), no. 5, 19-25.

9 Dinya L, Biomassza-alapú energiatermelés és fenntartható energiagazdálkodás (Biomass-based generation of energy and sustainable energy management), Magyar Tudomány 8 (2010), available at http://www.matud.iif.hu/2010/08/03.htm. Retrieved: 25. 03. 2012.

10 Dinya L, Domán Sz, Fodor M, Tamus A, Ökoenergetikai marketing kihívások (Eco-energetic marketing challenges), 2006. Conference proceedings on CD.

11 Duinker P, Greig L, Scenario analysis in environmental impact assessment: improving explorations of the future, Environmental Impact Assessment Review 27 (2007), no. 3, 206-219, DOI 10.1016/j.eiar.2006.11.001. cited in [35].

12 EEP - Európai Energia Portál, Izzólámpák kivonása (Withdrawment of filament bulbs), 2010, available at http://ec.europa.eu/energy/lumen/ faq/index_hu.htm Retrieved: 25. 03. 2012.

13 EPT - Európai Parlament és Tanács, 2010/31/EU irányelve az épületek energiahatékonyságáról (átdolgozás) (EU policy on the energy efficiency of buildings revised version), 2010, available at http://eur-lex.europa.eu/LexUriServ/LexUriServ.do?uri=0] : L:2010:153:0013:0035:HU:PDF Retrieved: 23. 03. 2012.

14 EREC - European Renewable Energy Council, Renewable Energy Roadmap up to 2020, 2007, available at http://wWw.erec.org/ fileadmin/erec_docs/Documents/Publications/EREC-Technoloy_ Roadmap_def1.pdf Retrieved: 23. 03. 2012.

15 Fábián Z, Kolosi T, Róbert P, Fogyasztás és életstílus (Consumption and lifestyle), Társadalmi riport 2000 (Kolosi T, Tóth I, Vukovich Gy, eds.), 2000, pp. 346-376. 
16 GKM - Gazdasági és Közlekedési Minisztérium, Magyarország megújuló energiaforrás felhasználás növelésének stratégiája 2007-2020 (Hungary's strategy for increasing the usage of renewable energy sources), GKM, Budapest, 2007.

17 Harangozó G, A javuló energiahatékonyság szerepe az energiafelhasználás csökkentésében: lehetôségek és buktatók (The role of improving energy efficiency in the reduction of energy consumption: opportunities and obstacles), BCE, Budapest, 2009, available at http://www.uni-corvinus. hu/index.php?id=26651 Retrieved: 23. 03. 2012.

18 Hronszky I, Várkonyi L, Radikális innovációk menedzselése (Managing radical innovations), Harvard Businessmanager 8 (2006), no. 10, 28-41.

19 IAE - Institute of Applied Energy: Japanese Ministry of Economy T. \& I., Strategic technology roadmap (energy sector) - energy technology vision 2100, 2005, available at http://www.iae.or.jp/2100/main.pdf Retrieved: 23. 03. 2012.

20 IAE - Institute of Applied Energy, Energy Technology Roadmaps a guide to development and implementation, OECD, 2010, available at http:// Www.iea.org/papers/roadmaps/guide.pdf Retrieved: 15. 03. 2012.

21 Jevons $\mathbf{W}$, The Coal question. An inquiry concerning the process of the nation, and the probable exhaustion of our coal-mines, MacMillan, London, 1865.

22 Kampas $\mathbf{P} \mathbf{J}$, Road Map to the E-Revolution, Information Systems Management 17 (2000), no. 2, 8-22, DOI 10.1201/1078/43191.17.2.20000301/31223.2.

23 KöBarEn, Lakossági átlag energiaárak (Average residential energy prices), Környezetbarát Energiák ( 2010), available at http://www.kobaren.hu/ energiaarak.html Retrieved: 10. 08. 2010.

24 KvVM - Környezetvédelmi és Vízügyi Minisztérium, Nemzeti Éghajlatváltozási Stratégia (National climate change strategy), 2007, available at klima.kvvm.hu/documents/14/NES_6.4c.pdf PRUDENCE project, Retrieved: 23. 03. 2012.

25 Kurzweil R, The Singularity Is Near, Viking Press, 2005. cited in [9].

26 Mahmoud M, Liu Y, Hartmann H, Stewart S, Wagener T, Semmens D, Stewart R, Gupta H, Dominguez D, Dominguez F, Hulse D, Letcher R, Rashleigh B, Smith C, Street R, Ticehurst J, Twery $\mathbf{M}$, van Delden H, Waldick R, White D, Winter L, A formal framework for scenario development in support of environmental decision-making, Environmental Modelling \& Software 24 (2009), no. 7, 798-808, DOI 10.1016/j.envsoft.2008.11.010. cited in [35].

27 Márgus N, Túl nagy a magyarok ökológiai lábnyoma, Reakció? (Hungarian's ecological footprint is too big. Reaction?), Vol. 4, 2007, available at http://fenntarthatojovo.hu/uploads/ujsag/reakcio2007junjul.pdf Retrieved: 23. 03. 2012.

28 McCarthy R C, Linking Technological Change to Business Needs, IEEE Engineering Management Review 31 (2003), no. 3, 49-53, DOI 10.1109/EMR.2003.24905.

29 McMillan A, Roadmapping - Agent of Change, IEEE Engineering Management Review 31 (2003), no. 3, 42-4, DOI 10.1109/EMR.2003.24904.

30 Medgyasszay P, Várható éghajlatváltozás hatása az épített környezetre (The effect of the expectable climate change to the built environment), 2007, available at http://fenntarthato.hu/epites/leirasok/nes/ eghajlatvaltozas-hatasa Retrieved: 23. 03. 2012.

31 Medgyasszay P, Fütési energia megtakaritás épület léptékben (Saving heating energy on the scale of buildings), 2007, available at http://fenntarthato.hu/epites/leirasok/nes/futes-epuletleptekben Retrieved: 23. 03. 2012.

32 MK - Miniszterelnöki Kormányrendelet, Kormányrendelet a lakásépitési támogatásról 256/2011. (XII. 6.) SZOCPOL 2012(Government regulation of home building subvention), 2011, available at http://www.google.hu/url?sa=t $\{\backslash \&\} \mathrm{rct}=$ $\mathrm{j}\{\backslash \&\} \mathrm{q}=\{\backslash \&\}$ esrc $=\mathrm{s}\{\backslash \&\}$ source $=$ web $\{\backslash \&\} \mathrm{cd}=1\{\backslash \&\} \mathrm{ved}=$
QCCQQFjAA $\backslash \&\}$ url=http $\{\%\} 3 \mathrm{~A}\{\%\} 2 \mathrm{~F}\{\%\} 2$ Fkozlony. magyarorszag. hu\{\%\}2Fpdf $\{\%\} 2 F 11106\{\backslash \&\}$ ei=2dhlT_G504Ttsgbhgp3fBQ $\{\backslash \&\}$ usg= AFQjCNFrhxa7QIDPf7ycZGOpkb83sUBGoA $\{\&\}$ sig2= KvXZWouWRn60iqCMEKpTOg Retrieved: 18. 03. 2012.

33 NeFMi - Nemzeti Fejlesztési Minisztérium, Nemzeti Energiastratégia 2030 (National Energy Strategy 2030), 2011, available at http: //www. kormany.hu/download/5/39/40000/Energiastrategia.pdf Retrieved: 23. 03. 2012.

34 Moen J, Jonsson R, Scenarios in the context of Future Forests, 2009, available at http://www.futureforests.se/download/18. 5686ae2012c08a47fb5800023704/Scenarios+in+the+context+of+ Future+Forests.+PDF.pdf Retrieved: 27. 09. 2012.

35 OMSZ - Országos Meteorológiai Szolgálat E.-M.-E. L. T., Éghajlati szélsôségek változásai Magyarországon: közelmúlt és jövő (Changes in the climate extremes in Hungary: near past and future), 2012, available at http://met.hu/omsz/OMSZ_hirek/index.php?id=114\{\\&\}hir= Hazai_eredmenyek_az_eghajlati_szelsosegek_magyarorszagi_ valtozasairolRetrived:17.03.2012

36 Pappné Vancsó J, Az ökológiai lábnyom számítási módszerének bemutatása Magyarország példáján keresztül (Introducing the calculation method of ecological footprint through the example of Hungary), Szeged, 2004, available at http://geography.hu/mfk2004/mfk2004/ phd_cikkek/pappne_vancso_judit.pdf Retrieved: 23. 03. 2012.

37 Pataki B, Szalkai Zs, Bíró-Szigeti Sz, Some Organizational Issues of Technology Roadmapping Experienced in Hungary, Periodica Polytechnica, Social and Management Sciences 33 (2010), no. 1, 31-38, DOI 10.3311/pp.so.2010-1.04.

38 PATH - Partnership for Advancing Technology in Housing, Technology Brainstorming - Energy Efficiency in existing homes, 2002, available at http://www. pathnet.org/sp. asp?id=1449 Retrieved: 23. 03. 2012.

39 PATH - Partnership for Advancing Technology in Housing, Strategies Defined, Energy Efficiency in existing homes, 2002, available at http:// WWW. pathnet.org/sp.asp?id=1449 Retrieved: 23. 03. 2012.

40 PATH - Partnership for Advancing Technology in Housing, Prioritized Action Plan, Energy Efficiency in existing homes, 2004, available at http: //www.pathnet.org/sp.asp?id=1449 Retrieved: 23. 03. 2012.

41 Phaal R, Farrukh C, Mitchell R, Probert D, Starting-up Roadmapping Fast, IEEE Engineering Management Review 31 (2003), no. 3, 54-60, DOI 10.1109/EMR.2003.24906.

42 Phaal R, Farrukh C, Probert D, Customizing Roadmapping, ResearchTechnology Management 47 (2004), no. 2, 26-37.

43 Phaal R, Public-Domain Roadmaps, Centre for Technology Management University of Cambridge, 2009, available at http://www.ifm.eng.cam. ac.uk/ctm/trm/documents/roadmap_biblio10_9_09.pdf Retrieved: 23. 03. 2012.

44 Poós M, Az energia termelés-fogyasztás és a szén-dioxid kereskedelem (Energy generation and consumption and carbon dioxid trading), GKM Energetikai Főosztály. Európa Universitas Szeminárium, Budapest, 2005, available at www.europauniversitas.hu/upload/ C02\{\%\}20kereskedelem.ppt Retrieved: 23. 03. 2012.

45 Postma T, Liebl F, How to improve scenario analysis as a strategic management tool?, Vol. 72, 2005, available at http://www.rug. nl/feb/Onderzoek/somAppliedResearch/Onderzoekscentra/ Healthcare_RHO/publicaties/wetenschapartikelen/ 2004PostmaTechnForecasting.pdf Retrieved: 23. 03. 2012.

46 PRB - Population Reference Bureau, 2010 World Population Data Sheet, Washington, 2010, available at http://www.prb.org/pdf10/10wpds_ eng.pdf Retrieved: 26. 03. 2012.

47 Probert D, Radnor M, Frontier Experiences from Industry-Academia Consortia, Research-Technology Management 31 (2003), 28, DOI 10.1109/EMR.2003.24902. 
48 Rubin J, Buchanan P, Crude Prices Will Almost Double Over Next Five Years, Vol. 53, 2005, available at http://research.cibcwm.com/ economic_public/download/occ_53.pdf Retrieved: 23. 03. 2012.

49 Shoemaker $\mathbf{P}$, Twenty common pitfalls in scenario planning, Learning from the future. Competitive Foresight Scenarios. (Fahey L, Randall R. M, eds.), 1998, pp. 422-431. cited in [35].

50 Szirmai $\mathbf{V}$, A modern fogyasztási modelleket meghatározó társadalmi mechanizmusok és érdekviszonyok. A fenntartható fogyasztás modellje (Social mechanisms and interest relations determining the modern consumption models, The model of sustainable consumption), MTA Szociológiai Intézet, Budapest, 2009, available at http://www.uni-corvinus.hu/index. php?id=26651 Retrieved: 23. 03. 2012.

51 Szlávik J, Füle M, Economic Consequences of Climate Change, Melbourne, USA, 2009. Conference proceedings.

52 Swartz P, The Art of the Long View, Doubleday, New York, 1991. cited in [35].

53 TNM - a regionális fejlesztésért és felzárkóztatásért felelős tárca nélküli miniszter(minister without portfolio regulation of determining the energetics characteristics of buildings), (7/2006. V.24.) TNM rendelet az épületek energetikai jellemzóinek meghatározásáról, 2006, available at http://net.jogtar.hu/jr/gen/hjegy_doc.cgi?docid= A0600007.TNM Retrieved: 23. 03. 2012.

54 Ürge-Vorsatz D, Pálvölgyi T, Füle M, Szlávik J, Fenntartható energiagazdálkodás és környezetvédelem (Sustainable energy management and environmental protection), BME, Budapest, 2000. 